\title{
Bedah Reposisi Hernia Perineal pada Kucing Betina
}

\section{Perineal Hernia Reposition Surgery in a Female Cat}

\author{
Desty Apritya $^{1 *}$, Ratna Widyawati ${ }^{1}$, Erfan Andrianto Aritonang ${ }^{2}$, Marselinus Ndilu \\ Landu Djawa ${ }^{2}$, Fauzi Saputra ${ }^{2}$, Ika Ayu Anita Dayanti ${ }^{2}$ \\ ${ }^{1}$ Laboratorium Bedah dan Radiologi Veteriner, ${ }^{2}$ Mahasiswa PPDH \\ Fakultas Kedokteran Hewan, Universitas Wijaya Kusuma Surabaya \\ Jl. Dukuh Kupang Barat XXV no 54 Surabaya \\ *Corresponding author: destyapritya@uwks.ac.id
}

\begin{abstract}
Abstrak
Kucing betina berusia \pm 1 tahun dengan gejala klinis dysuria, konstipasi, pada bagian perineal terdapat kebengkakan dengan konsistensi kenyal disertai luka. Hasil pemeriksaan darah menunjukkan peningkatan monosit sedangkan hasil pemeriksaan ultrasonografi pada kebengkakan menunjukan gambaran anechogenic berisi cairan. Hasil aspirasi teridentifikasi cairan tersebut adalah urin, sehingga kucing tersebut dapat didiagnosis hernia perineal dengan refleksi vesika urinaria. Tahapan operasi meliputi herniorraphy, reposisi vesika urinaria, dan hernioplasti. Terapi sistemik pasca operasi yaitu Amoxicilin $20 \mathrm{mg} / \mathrm{kgBB}$ q12h, Asam mefenamat $16 \mathrm{mg} / \mathrm{kg}$ BB q12h, dan multivitamin $1 / 2$ tab q12h selama tujuh hari. Terapi menggunakan topikal menggunakan povidone iodine $10 \%$ dan die da yao jing ${ }^{\circledR}$. Kucing menunjukkan aktifitas normal setelah 7 hari perawatan.
\end{abstract}

Kata kunci: hernia perineal, kucing, bedah reposisi

\section{Abstract}

A year old female cat with clinical symptoms of dysuria, constipation, perineal swelling with a lumpy consistency accompanied by a wound. Haematological evaluation result showed an increase in monocytes meanwhile ultrasonography examination result on the perineal swelling showed anechogenic with fluid. The result of aspiration identified by the fluid was urine. It could be diagnosed with perineal hernia by the bladder retroflexed. Stages of surgery include herniorraphy, bladder reposition, and hernioplasty. Postoperative systemic therapy were used Amoxicilin $20 \mathrm{mg} /$ body weight q12h, Asam mefenamat $16 \mathrm{mg} / \mathrm{kg}$ body weight q12h, and multyvitamin $1 / 2$ tab q12h for a week. Topical therapy were used povidone iodine $10 \%$ and de dai yo jing ${ }^{\circledR}$. The cat showed normal behaviour on seven days post treatment.

Keywords: hernia perineal, cat, reposition surgery

Received: 21 Mei 2020

Revised: 8 Juli 2020

Accepted: 11 Agustus 2020

\section{PENDAHULUAN}

Hernia adalah keluarnya visceral abdominal melalui suatu lubang ke dalam kantong yang dilapisi oleh peritonium, tunika flava dan kulit (Antari dkk., 2018). Ada berbagai jenis hernia, salah satunya adalah hernia perineal. Hernia perineal merupakan suatu keadaan melemahnya atau terpisahnya muskulus yang terdapat di area pelvis hal ini menyebabkan translokasi organ visera abdomen ke perineal subkutaneus. Organ yang dapat mengalami translokasi ke kantung hernia antara lain prostat, vesica urinaria, dan intestinal (Tobias, 2010).
Penyebab primer hernia dapat terjadi secara kongenital yaitu karena kelainan sejak lahir (Rosita dkk., 2019). Penyebab sekunder hernia perineal terjadi akibat kejadian gangguan pada saluran urogenital atau penyakit prostat terutama pada kucing (Monnet, 2013). Menurut Fossum (2019) penyebab lainnya yaitu prostatitis, cystitis, obstruksi saluran kemih, obstruksi colorectal, inflamasi perianal, anal sacculitis, diare dan konstipasi.

Williams (2009) menyatakan kasus hernia perineal dapat terjadi pada anjing dan kucing namun paling sering terjadi pada anjing. Hayashi et al. (2016) melaporkan, 182 anjing didiagnosis 
hernia perineal, $94 \%$ terjadi pada anjing jantan dan $4 \%$ tejadi pada anjing betina. Faktor komorbid terkait hernia perineal pada anjing betina antara lain trauma pada panggul, batuk persisten sekunder akibat bronkitis, kolaps trakea dan cardiopathy (anjing berukuran kecil). Kasus pada kucing dilaporkan Galanty (2005), kantung hernia perineal berisi rektum yang berisi feses dan lemak retroperitonial serta adapula kasus yang berisi vesica urinaria atau terjadi retrofleksi vesica urinaria.

Gejala klinis hernia perineal pada umumnya berupa tenesmus karena kesulitan defekasi dan urinasi (Gill dan Barstad, 2018). Hernia perineal yang terjadi retrofleksi vesica urinaria gejala klinis yang dapat ditimbulkan yaitu stranguria, disuria dan anuria (Bojrab et al., 2014). Diagnosis hernia perineal dapat dilakukan berdasarkan pemeriksaan fisik dengan ditunjang pemeriksaan darah, dan ultrasonografi.

Penanganan bedah reposisi hernia perineal, meliputi teknik tradisional atau reposisi anatomi dan internal obturator atau teknik transposisi. Teknik internal obturator transposisi lebih sulit dilakukan terutama apabila $M$. internal obturator mengalami atropi. Teknik herniorraphy lainnya dapat menggunakan M. gluteal superficial, $M$. semitendinosus, $M$. semimembranosus, $M$. fascia lata, menutup dengan sintetik mesh, submukosa usus halus dan kolagen dermal (Fossum, 2019).

\section{METODE}

\section{Sinyalemen, Anamnesa, dan Gejala Klinis}

Seekor kucing betina usia \pm 1 tahun dengan berat badan $3.5 \mathrm{~kg}$ mengalami dysuria, konstipasi, pada bagian perineal terdapat kebengkakan dengan konsistensi kenyal disertai luka. Menurut keterangan pemilik, kebengkakan pada daerah perineal telah teridentifikasi selama \pm 4 bulan. Hewan menunjukkan rasa tidak nyaman saat duduk.

\section{Uji Pendukung, Diagnosa, Diagnosa Pembanding, dan Prognosa}

Uji pendukung pada kasus ini adalah dilakukan pemeriksaan darah lengkap dan ultrasonografi. Pemeriksaan darah dilakukan untuk menilai status klinis kucing, sedangkan pemeriksaan ultrasonografi dilakukan untuk mengetahui isi kebengkakan. Diagnosa untuk kasus ini adalah hernia perineal. Diagnosa pembandingnya antara lain perianal neoplasia, perianal gland hyperplasia, anal sac abses. Prognosa hewan pada kasus ini adalah fausta.

\section{Anaestesi}

Tindakan anaestesi yang dilakukan meliputi pre anastesi menggunakan Atropin (Atropin inj ${ }^{\circledR}$ ) $0.04 \mathrm{mg} / \mathrm{kgBB}$ dan Acepromazin $\left(\right.$ Castran $\left.^{\circledR}\right) 0.05$ $\mathrm{mg} / \mathrm{kgBB}$. Anastesi umum menggunakan Ketamin $\left(\right.$ Ketamil $\left.^{\circledR}\right) 20 \mathrm{mg} / \mathrm{kgBB}$.

\section{Teknik Bedah}

Teknik bedah yang dilakukan untuk melakukan reposisi hernia perineal yaitu teknik tradisional atau reposisi. Tahapannya yaitu herniorraphy, reposisi vesica urinaria, dan hernioplasti (Fossum, 2019).

Posisi rebah hewan adalah sternal recumbency. Insisi di lakukan pada kulit samping kebengkakan yang berisi vesica urinaria, dimulai dari pangkal ekor hingga medial tuberositas ischial. Kantung hernia dibuka dengan preparasi tumpul (Hobbs et al., 2014). Vesica urinaria yang mengalami retrofleksi dipisahkan dengan jaringan sekitar secara preparasi tumpul, lalu dilakukan reposisi vesica urinaria ke dalam abdomen. Vesica urinaria dipastikan masuk ke abdomen dengan laparotomi insisi pada midline caudal umbilikus. Teknik selanjutnya yaitu dilakukan hernioplasti. Penjahitan dilakukan pada $M$. eksternal anal sphincter, M. levator ani dan $M$. coccygeal dengan pola terputus sederhana menggunakan benang absorble asam poliglikonic $\left(\mathrm{Safil}^{\circledR}\right)$ ukuran 3.0, dan lapisan kulit menggunakan benang silk ukuran 3.0. Penutupan laparotomi yaitu menjahit linea alba dengan pola terputus sederhana, lapisan subkutan ditutup dengan pola jahitan menerus sederhana dan lapisan kulit ditutup dengan pola jahitan terputus sederhana.

\section{Post Operasi}

Terapi yang di berikan pasca operasi adalah injeksi asam tolfenamic $0.1 \quad \mathrm{ml} / \mathrm{kg} \quad \mathrm{BB}$ 
$\left(\right.$ Tolfedin $\left.^{\circledR}\right)$. Terapi oral yang diberikan antara lain Amoxicilin $20 \mathrm{mg} / \mathrm{kgBB}$ q12h, Asam mefenamat $16 \mathrm{mg} / \mathrm{kgBB}$ q12h, dan multivitamin $1 / 2$ tab q12h $\left(\right.$ Caviplex $\left.^{\circledR}\right)$. Terapi topikal yang diberikan adalah povidone iodine $10 \%$ dan die da yao jing ${ }^{\circledR}$.

\section{HASIL DAN PEMBAHASAN}

Hasil pemeriksaan darah menunjukkan hewan mengalami kenaikan monosit (Tabel 1). Monosit merupakan sel radang kronis, apabila berpindah ke jaringan monosit disebut dengan makrofag atau selain yang diklasifikasikan sebagai sel fagositik. Jumlah monosit yang meningkat dari normal merupakan indikasi bahwa hewan mengalami inflamasi kronis. Peningkatan jumlah monosit yang terjadi pada kasus ini disebabkan karena adanya luka pada bagian kulit luar (perineal) yang mengalami penonjolan, sehingga respon imun tubuh non spesifik yaitu monosit segera meningkat untuk melakukan fagositosis (Day et al., 2000).

Hasil ultrasonografi dengan menempelkan probe pada bagian kebengkakan di perineal menunjukkan gambaran anechogenic, yang berarti bahwa kebengkakan pada perineum tersebut berisi cairan. Cairan tersebut di konfirmasi dengan hasil sonogram acoustic enchancement artifact (Gambar 1). Acoustic enchancement artifact merupakan gambaran sistem ultrasonografi yang mengasumsikan atenuasi apabila probe bertemu dengan struktur organ yang sangat kuat atau lemah, sehingga akan timbul bayangan yang lebih terang (Quien dan Saric, 2018). Isi cairan tersebut dikonfirmasi dengan aspirasi menggunakan disposible syring 3 cc pada bagian yang bengkak. Hasil aspirasi menunjukan cairan tersebut adalah urin, sehingga di ketahui bahwa bagian yang bengkak tersebut adalah vesica urinaria. Kasus hernia dimana kantung berisi vesica urinaria maka dapat disebut cystocele (Sudisma dkk., 2006). Retrofleksi vesica urinaria ke dalam kantung hernia menyebabkan obstruksi saluran kemih, sehingga dapat menyebabkan nefropati dan berakibat kematian oleh karena itu kasus ini perlu dilakukan tindakan operasi (Morgan, 2008).

Beberapa teknik yang dapat dilakukan untuk perbaikan hernia perineal diantaranya yaitu Internal Obturator Muscle Flap (IOMF), Semitendinosus Muscle Flap (SMF), serta reposisi anatomi (Ladlow et al., 2014). Teknik bedah untuk penanganan hernia perineal yang dilakukan pada kasus ini adalah teknik tradisional atau reposisi anatomi. Tahapan bedah reposisi hernia perineal antara lain herniorraphy (pergerakan kantong hernia), reposisi vesica urinaria, dan hernioplasti (penjahitan kantung hernia) (Monnet, 2013).

Kucing diposisikan sternal recumbency dengan ekor ditarik ke arah cranial sedangkan kaki belakang tergantung pada ujung meja. Posisikan kaki belakang dan ujung meja dengan bantalan untuk mencegah neuropraxia atau kerusakan otot pasca operasi. Enema dan penutupan anal dengan pola jahitan purse string dapat dilakukan untuk menghindari kontaminasi saat operasi (Ladlow et al., 2014).

Insisi pada kulit dengan sayatan curvilinear disamping kebengkakan, dimulai dari pangkal ekor hingga medial tuberositas ischial. Metode herniorraphy dilakukan untuk mengidentifikasi cincin hernia, setelah ditemukan cincin pada anterior perineal hernia, dilanjutkan dengan preparasi tumpul untuk memisahkan perlekatan antara vesica urinaria dengan jaringan ikat disekitarnya. Cystocentesis melalui perineal direkomendasikan pada hernia perineal yang terjadi retrofleksi vesica urinaria (Fossum, 2019). Adhesi yang cukup luas ditemukan pada kasus ini, sehingga perlu dilakukan laparotomi untuk membantu reposisi vesica urinaria (Brissot et al., 2004).

Cystopexy direkomendasikan untuk mencegah keluarnya kembali vesica urinaria dari abdomen (Risselada et al., 2003). Tindakan selanjutnya dilakukan hernioplasti atau penjahitan bagian cincin hernia untuk penutupan cincin hernia. Posisikan M. eksternal anal sphincter pada $M$. levator ani dan $M$. coccygeal pada bagian lateral serta posisikan M. eksternal anal sphincter dengan $M$. internal obturator pada bagian ventral. Penjahitan dilakukan pada 
Tabel 1. Hasil pemeriksaan darah pada kucing

\begin{tabular}{lccc}
\hline Parameter & Satuan & Hasil & Nilai Normal \\
\hline WBC & $10^{3} / \mathrm{uL}$ & 9.20 & $5.5-19.5$ \\
Limfosit & $10^{3} / \mathrm{uL}$ & 4.04 & $1.5-7$ \\
Monosit & $10^{3} / \mathrm{uL}$ & 2.3 & $0-0.9$ \\
Limfosit & $\%$ & 44 & $27-36$ \\
Monosit & $\%$ & 25 & $0-5$ \\
RBC & $10^{6} / \mathrm{uL}$ & 7.62 & $5-10$ \\
$\mathrm{Hgb}$ & $\mathrm{g} / \mathrm{dl}$ & 13.3 & $9.8-15.4$ \\
$\mathrm{HCT}$ & $\%$ & 35.12 & $30-45$ \\
$\mathrm{MCV}$ & $\mathrm{fL}$ & 46.1 & $39-55$ \\
$\mathrm{MCH}$ & $\mathrm{pg}$ & 17.5 & $13-17$ \\
MCHC & $\mathrm{g} / \mathrm{dl}$ & 33.4 & $30-36$ \\
\hline
\end{tabular}

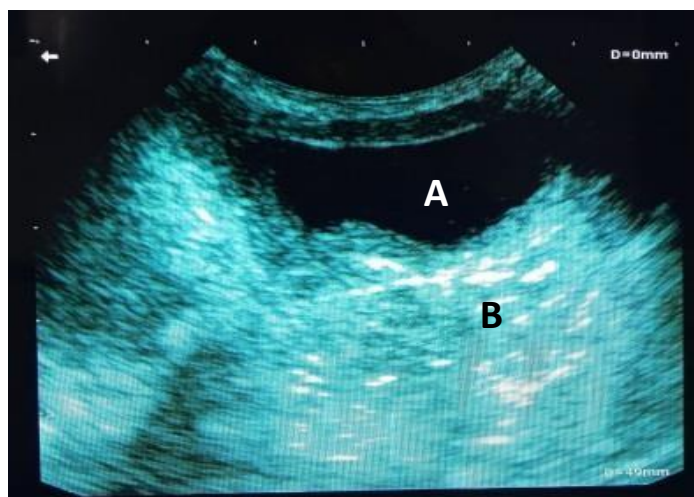

Gambar 1. Gambaran ultrasonografi (probe ditempel pada kebengkakan).

(A) kantung berisi cairan, (B) acoustic enchancement artifac

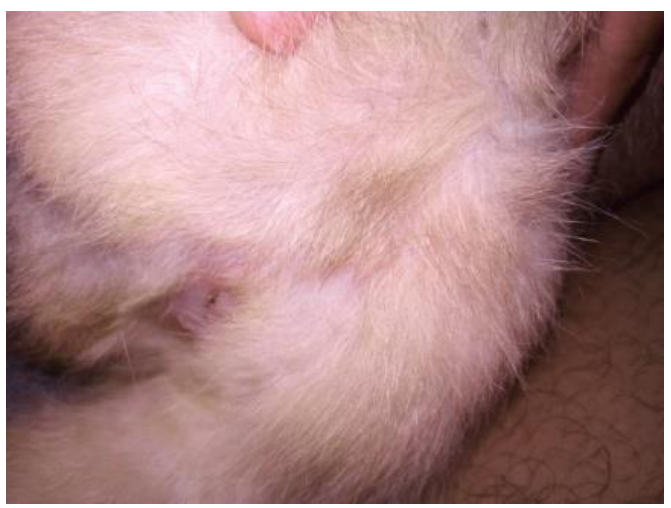

Gambar 2. Kesembuhan luka insisi pada kulit setelah 2 bulan

M. levator ani dan M. coccygeal yang merupakan muskulus yang membentuk pelvic diafragma (Tobias, 2010). Kulit ditutup dengan menggunakan pola jahitan terputus sederhana menggunakan benang silk berukuran 3.0. Laparotomi ditutup dengan melakukan penjahitan pada linea alba, subkutan dan kulit.

Terapi sistemik yang diberikan pasca operasi adalah Amoxicilin $20 \mathrm{mg} / \mathrm{kgBB} \mathrm{q} 12 \mathrm{~h}$, Asam mefenamat $16 \mathrm{mg} / \mathrm{kgBB}$ q12h, dan multivitamin $1 / 2$ tab q12h $\left(\right.$ Caviplex $\left.^{\circledR}\right)$ selama tujuh hari. Terapi topikal yang diberikan adalah povidone iodine $10 \%$ dan die da yao jing ${ }^{\circledR}$. Pemberian pelunak feses suppositoria $\mathrm{q} 48 \mathrm{~h}$ bertujuan menghindarkan hewan dari kemungkinan terjadinya impaksi feses (Hobbs et al., 2014).

Pemasangan elizabeth collar selama perawatan pasca operasi guna menghindarkan hewan untuk menjilati area luka jahit (Gambar 2). Tujuh hari pasca operasi, kucing dapat urinasi dan defekasi secara normal. 


\section{KESIMPULAN}

Diagnosa hernia perineal dapat dilakukan dengan melakukan pemeriksaan penunjang menggunakan ultrasonografi dan pemeriksaan darah. Teknik bedah reposisi hernia perineal dengan retrofleksi vesica urinaria adalah teknik tradisional atau reposisi anatomi. Tahapan prosedur bedah reposisi hernia perineal meliputi herniorraphy, reposisi vesica urinaria, dan hernioplasti.

\section{UCAPAN TERIMA KASIH}

Penulis mengucapkan terima kasih kepada pemilik kucing di Sidoarjo dan mahasiswa PPDH Fakultas Kedokteran Hewan Universitas Wijaya Kusuma Surabaya.

\section{DAFTAR PUSTAKA}

Antari, G.A.M.S., Wirata, I.W., Wardhita, A.A.G.J. 2018. Studi Kasus: Operasi Penanganan Hernia Umbilikalis pada Anjing Ras Campuran Pomeranian. Indonesia Medicus Veterinus, 7(6), 597-607.

Bojrab, M.J., Waldron, D.R., Toombs, J.P. 2014. Surgical Techniques for Treatment of Perineal Hernia. Current Techniques in Small Animal Surgery, Fifth Edition. Teton New Media. pp: 569-582.

Brissot, H.N., Dupre, G.P., Bouvy, B.M. 2004. Use of laparotomy in a staged approach for resolution of bilateral or complicated perineal hernia in 41 dogs. Vet. Surg., 33, 412-421.

Day, M.J., Mackin, A., Littlewood, J.D. 2000. Disorders of Leucocyte Number. Manual of Canine and Feline Haematology and Transfusion Medicine. BSAVA. Pp: 93-99.

Fossum, T.W. 2019. Perineal Hernia. Small Animal Surgery Fifth Edition. Mosby. pp: 496-437.
Galanty, M. 2005. Perineal Hernia in 3 Cats. Pol. J. Vet. Sci., 8(2), 165-8.

Gill, S.S., Barstad, R.D. 2018. A Review of the Surgical Management of Perineal Hernias in Dogs. J. Am. Anim. Hosp. Assoc., 54(4), 179-187.

Hayashi, A.M., Rosner, S.A., Assumpcao, T.C.A., Stopiglia, A.J., Matera, J.M. 2016. Retrospective Study (2009-2014): Perineal Hernias and Related Comorbidities in Bitches. Top Companion Anim. Med. 31(4), 130-133.

Hobbs, S.J.L., Demetriou, J.L., Ladlow, J.F. 2014. Hernia Perineal. Feline Soft Tissue and General Surgery. Saunders Elsevier. pp: 271-279.

Ladlow, J.F., Demetriou, J.L., Hobbs, S.J.L. 2014. Perineal Hernia. Feline Soft Tissue and General Surgery. Elsevier. pp: 277-279.

Monnet, E. 2013. Perineal Hernias. Small Animal Soft Tissue Surgery. WileyBlackwell. pp: 286-295.

Morgan, R.V. 2008. Diseases of The Anus and Perianal Region.Handbook of Small Animal Practice (Fifth Edition). Elsevier.

Quien, M.M., Saric, M. 2018. Ultrasound imaging artifacts: How to recognize them and how to avoid them. Wiley Echocardiography. pp: 1-14.

Risselada, M., Kramer, M., Van de Velde, B., Polis, I., Gortz, K. 2003. Retroflexion of the Urinary Bladder Associated With a Perineal Hernia in a Female Cat. J. Small Anim. Pract., 44(11), 508-10.

Rosita, I., Sudisma, I.G.M., Gorda, I.W. 2019. Laporan Kasus: Penanganan Hernia Umbilikalis pada Kucing Lokal Betina Umur Sembilan Tahun dengan Laparotomi. Indonesia Medicus Veterinus, 8(6), 728-738. 
Sudisma, I.G.N., Pemayun, I.G.A.G., Wardhita, A.A.G.J., Gorda, I.W. 2006. Ilmu Bedah Veteriner dan Teknik Operasi. Denpasar: Pelawa Sari.
Tobias, K.M. 2010. Perineal Hernia.Manual of Small Animal Soft Tissue Surgery. WileyBlackwell. pp: 339-346.

Williams, J. 2014. Perineal Hernia. World Small Animal Veterinary Association World Conggres Proceding. 2014. 